\title{
Fluid and Silicate-Melt Inclusions and Interstitial Glass in Mantle Xenoliths from Melanephelinites of the Udokan Lava Plateau, Russia.
}

\author{
Sharygin, V.V. ${ }^{1}$, Litasov, K.D. ${ }^{2}$, Smirnov, S.Z. ${ }^{1}$, Kuzmin, D.V. ${ }^{1}$, Reutsky V. N. ${ }^{1}$, and Ivanov A.V. ${ }^{3}$ \\ 1. Institute of Mineralogy and Petrography, 630090 Novosibirsk, Russia. \\ 2. Institute of Geology, 630090 Novosibirsk, Russia. \\ 3. Institute of the Earth crust, 664033 Irkutsk. Russia \\ E-mails: sharygin@aiggm.nsc.ru, kostik@uiggm.nsc.ru, smirnov@uiggm.nsc.ru. kuzmin@auiggm.nsc.ru
}

The central volcanoes in the northern Udokan lava field (Ingamakit, Munduzhyak, Lurbun and others) are composed mainly of melanephelinites. The rocks contain olivine (Mg\# - 0.7-0.85) and zoned Ti-augite (Mg\# - 0.83-0.95) as phenocrysts, and groundmass consisting of Ti-augite (Mg\# - 0.7-0.8), Ti-magnetite, apatite, nepheline, leucite, Ba-Ti-phlogopite (Mg\# - 0.55-0.75), ilmenite, rarely K-feldspar, sulfides, and glass. These rocks also contain numerous mantle xenoliths and megacrysts up to $10-15 \mathrm{~cm}$ in size. The recent isotopic dating performed for a sample from the

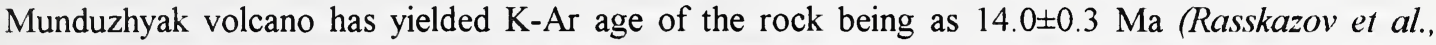
1997). Three different types of mantle xenoliths from melanephelinites has been studied by fluid inclusions: spinel lherzolite (Nizhnii Lurbun extrusion), ferrious harzburgite (Ingamakit volcano) and wehrlite (Munduzhyak volcano). The interstices in these xenoliths are filled with the following assemblages: olivine $+\mathrm{Cr}$-clinopyroxene $+\mathrm{Cr}$-spinel + sulfides + glass (or sanidine, leucite); olivine + ilmenite + rhönite \pm Ti-phlogopite + leucite, and association similar to melanephelinite groundmass. The presence of the reactionary rims is typical of some primary xenolith minerals (clinopyroxene, spinel). The essential phases (olivine, clinopyroxene) of the interstitial associations drastically differ in chemistry from primary xenolith minerals and approach the central zones of melanephelinite phenocrysts. Fluid, silicate-melt and sulfide inclusions were observed both in primary xenolith minerals and in the interstitial minerals.

\section{Wehrlite, the Munduzhyak volcano.}

Secondary high-density $\mathrm{CO}_{2}$ inclusions $\left(\mathrm{T}_{\mathrm{hom}}=-18^{\circ} \mathrm{C}, \rho=1.034 \mathrm{~g} / \mathrm{cm}^{3}\right)$ were found in primary olivine. They occur along independent healed microfractures in the host olivine and are not associated with silicate-melt inclusions $\left(\mathrm{T}_{\text {hom }}=1000-1100^{\circ} \mathrm{C}\right)$. Unfortunately, the direct data on trapping temperature of these fluid inclusions are absent. However, homogenization temperature of the secondary silicate-melt inclusions may be roughly considered as minimum temperature of the $\mathrm{CO}_{2}$ inclusion trapping. Consequently, trapping pressure of the $\mathrm{CO}_{2}$ inclusions may be estimated as $8.3-8.9 \mathrm{~kb}$ at $1000-1100^{\circ} \mathrm{C}$. The similar $\mathrm{CO}_{2}$-rich inclusions have been also found in mantle xenoliths from different suites (Schiano and Clocchiatti, 1994; Szabo and Bodnar, 1996; Varela et al., 1997). Nevertheless, it should take into account that initial melanephelinitic melt $\left(1200-1250^{\circ} \mathrm{C}\right)$ may be the most real source for these $\mathrm{CO}_{2}$ inclusions, and pressure may be estimated as $9.6-10 \mathrm{~kb}$.

\section{Spinel lherzolite, the Nizhnii Lurbun extrusion.}

Silicate-melt and fluid inclusions were found both in primary xenolith minerals and in the interstitial phases. Secondary silicate-melt inclusions occur along healed or partially healed fractures in the xenolith olivine. Their phase composition is glass + low-density fluid + rare daughter/trapped crystals (Cr-spinel, $\mathrm{Cr}$-clinopyroxene). Homogenization of the inclusions occurred at $1050-1100^{\circ} \mathrm{C}$. Primary silicate-melt and low-density fluid inclusions were also observed in the interstitial olivine and clinopyroxene (10-30 $\mu \mathrm{m})$. Melt inclusions consist mainly of glass, with variable amounts of lowdensity fluid (possibly, $\mathrm{N}_{2}$ ) and daughter crystals (ilmenite, apatite and others). $\mathrm{T}_{\text {hom }}$ are $>1200^{\circ} \mathrm{C}$ for olivine-hosted inclusions and $1200-1225^{\circ} \mathrm{C}$ - for clinopyroxene-hosted ones. Besides melt inclusions, the single crystals of nepheline, leucite and Ti-magnetite are typical of the interstitial clinopyroxene. 
Electron microprobe analysis showed that glasses of melt inclusions in the xenolith olivine and the interstitial minerals are similar in composition and close to intraxenolith glass. All these glasses strongly differ from inclusion glasses hosted by melanephelinite minerals in high $\mathrm{SiO}_{2}$ (up to 75 wt.\%), low $\mathrm{Al}_{2} \mathrm{O}_{3}$ (up to 15 wt.\%) and alkalis ( up to 10 wt.\%) (see Figure). According to SIMS data, intraxenolith glass contains up to $3.5 \mathrm{wt} \% \mathrm{H}_{2} \mathrm{O}, 260 \mathrm{ppm} \mathrm{Cr}, 500 \mathrm{ppm} \mathrm{Sr}$, and $720 \mathrm{ppm} \mathrm{Ba}$ and has OIB-like REE-pattern with slight enrichment in LREE.

\section{Harzburgite, the Ingamakit volcano.}

Magmatic inclusions were also found both in primary xenolith minerals and in the interstitial phases. Secondary silicate-melt, sulfide and fluid inclusions, and their different combinations (silicatemelt inclusions with sulfide isolation, fluid-sulfide inclusions, etc.) were observed in the xenolith olivine and orthopyroxene. All these inclusion types occur along healed fractures in the xenolith minerals. Silicate-melt inclusions consist mainly of glass, with variable amounts of fluid and daughter/trapped crystals (ilmenite, leucite, nepheline). Their homogenization occurred at $\mathrm{T}>1100^{\circ} \mathrm{C}$. Fluid phase in some inclusions consists of $\mathrm{CO}_{2}$ with variable density $\left(\mathrm{T}_{\text {hom }}=+3.5-8^{\circ} \mathrm{C}\right)$, while in majority of silicate-melt and fluid-sulfide inclusions it is low-density non-identified gas. Sulfide blebs consist of MSS, pentlandite, chalcopyrite. Primary silicate-melt inclusions (glass + fluid) occur rarely in the interstitial olivine. The chemistry of inclusion glasses in xenolith and interstitial minerals is very similar to K-feldspar and approaches that of glasses from the Nizhnii Lurbun lherzolite (see Figure).

\section{Origin of glasses.}

Now there are four possible models for the origin of trapped melts and fluids occurring as magmatic inclusions or interstitial associations in mantle xenoliths $\left(O^{\prime}\right.$ Connor et al., 1996; Schiano and Clocchiatti, 1994; Szabo et al., 1996; etc.): (1) infiltration by melts from the host magmas during transport to the surface; (2) anhydrous partial melting of upper mantle during decompression; (3) breakdown of mantle hydrous phases during decompression; (4) infiltrating melts, prior to entrainment into the host magma, related to some small-volume metasomatic mantle fluids. We suggest that the first model is more applicable for explaining of the origin of the magmatic inclusions and glasses in the Udokan mantle xenoliths. Nevertheless, it does not excluded that partial reaction between mantle xenolith and the host melanonephelinite magma might be possible. Thus, fluid, sulfide and silicate-melt inclusions found in xenolith minerals are fixed at least two stages for the influence of melanephelinite magma on mantle xenolith during its transport to the surface: at $\mathrm{P}>8,5$ $\mathrm{kb}$ and $\mathrm{T}=1100-1200^{\circ} \mathrm{C}$ - the low crust - upper mantle conditions; at $\mathrm{P}<5 \mathrm{~kb}$ and $\mathrm{T}=1000-1100^{\circ} \mathrm{C}$ the middle crust-near-surface conditions. The initial magma appeared to react actively with mantle xenolith minerals during the invasion. The following data are evidenced about this reaction: (1) the presence of the reactionary rims around xenolithic clinopyroxene and spinel, rarely orthopyroxene; (2) the presence of leucite and nepheline in the reactionary rim of xenolith clinopyroxene; (3) the similar chemistry of the reactionary rims from xenolith clinopyroxene and the central zone of melanephelinite clinopyroxene. It should be also noted that the majority of the above processes might occurred at $\mathrm{P}<5 \mathrm{~kb}$ (stability limit for leucite). Intraxenolith glass seems to represent a derivate of melanephelinite magma after leucite and nepheline crystallization. At present, this is a preliminary scheme of relationships between the host magma and mantle xenolith on the Udokan lava field.

This study was supported by the Russian Foundation of Basic Research (grants № 97-0565309 and 97-05-65331) and Siberian Branch of RAS (grant for young scientists)

\section{References}

O'Connor. T.K., Edgar A.D.. and Lloyd F.E.. 1996, Origin of glass in Quaternary mantle xenoliths from Meerfeldermaar. West Eifel. Germany: implications for enrichment in the lithospheric mantle: Can. Mineral., 34, p. 187-200.

Rasskazov, S.V., Boven. A., Andre, L., Liegeois, J-P., Ivanov, A.V., and Punzalan, L., 1997, Evolution of magmatism in the northeastern Baikal rift system: Petrologiya, 5, p.115-136. 
Schiano. P. and Clocchiatti, R., 1994. Worldwide occurrence of silica-rich melts in sub-continental and sub-oceanic mantle minerals: Nature, 368, p. 621-624.

Szabo, Cs. and Bodnar, R.J., 1996. Changing magma ascent rates in the Nógrád-Gömör volcanic field Northern Hungary/Southern Slovakia: Evidence from $\mathrm{CO}_{2}$-rich fluid inclușions in metasomatized upper mantle xenoliths: Petrologiya, 4(3), p. 240-249.

Szabo, Cs., Bodnar. R.J. and Sobolev. A.V., 1996. Metasomatism associated with subduction-related. volatile-rich silicate melt in the upper mantle beneath the Nógrád-Gömör volcanic field Northern Hungary/Southern Slovakia: Evidence from silicate-melt inclusions: Eur. J. Mineral., 8, p. 881-899.

Varela, M.E., Bjerg, E.A., Clocchiatti. R., Labudia. C.H. and Kurat, G., 1997. Fluid inclusions in upper mantle xenoliths from Northern Patagonia Argentina: evidence for an upper mantle diapir: Mineral. Petrol., 60 (3-4).

Figure.

Chemical variations of glasses from mantle xenoliths and host melanephelinite (Udokan lava field).
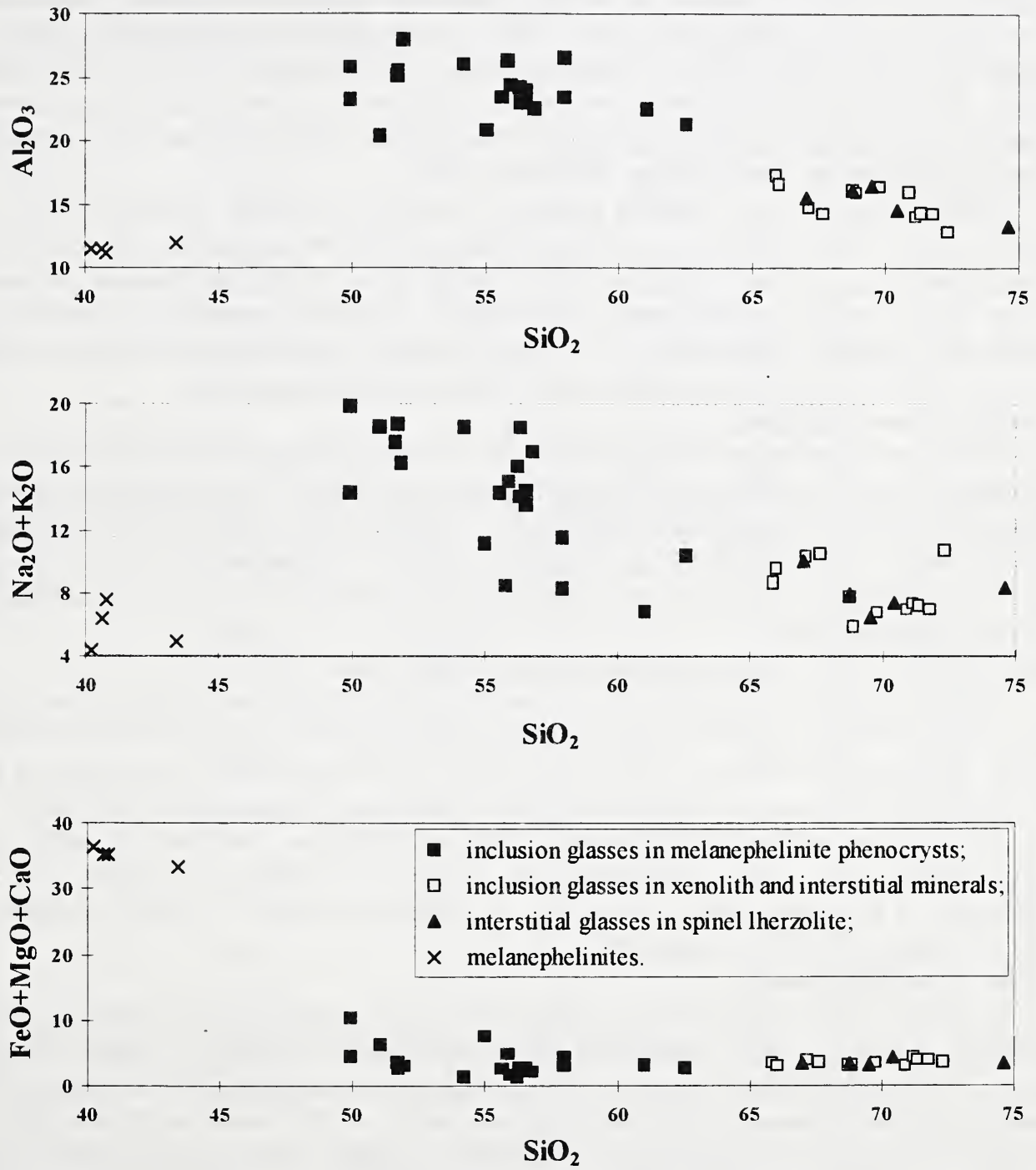